\title{
CONVERSION TO BIOGAS OF HERBACEOUS PLANTS, USED FOR OIL HYDROCARBONS CONTAMINATED SOILS CLEANING
}

Mantas RUBEŽIUS, Institute of energy and biotechnology engineering, Faculty of Agricultural Engineering, Aleksandras Stulginskis University, Studentų g. 11, LT-53361 Akademija, Lithuania, mantas.rubezius@ gmail.com

Kęstutis VENSLAUSKAS, Institute of energy and biotechnology engineering, Faculty of Agricultural Engineering, Aleksandras Stulginskis University, Studentų g. 11, LT-53361 Akademija, Lithuania; kestutis.venslauskas@ asu.lt (corresponding author)

Kęstutis NAVICKAS, Institute of energy and biotechnology engineering, Faculty of Agricultural Engineering, Aleksandras Stulginskis University, Studentų g. 11, LT-53361 Akademija, Lithuania; kestutis.navickas@ asu.lt

Fossil fuel demand growth in and price fluctuation, depletion resources and supply monopolize, climate change is forcing the restructuring of energy and other industrial and transport area, seeking for renewable energy sources. Using phytoremedial methods in biomass engineering, there is a possibility to create a sustainable method of biomass growth in mid-low contaminated sites soil system. Main aim of the research was to assess the oil-contaminated soil treatment herbaceous plants and their subsequent use for biogas production in order to create a closed cleaning and plant biomass utilization cycle.

After the evaluation of the biogas yield and energy conversion efficiency performance it was found that all of the selected herbaceous plant biomass is suitable as raw material for the production of biogas. The biogas potential of selected plants ranged from 377.2 to $822.9 \mathrm{l} / \mathrm{kg}$ dry organic matter with an energy value ranging from $7.1 \mathrm{MJ} / \mathrm{kg}$ to $17.1 \mathrm{MJ} / \mathrm{kg}$.

Keywords: biogas, herbaceous plants, oil hydrocarbons, phytoremediation.

\section{INTROCUCTION}

Fossil fuel demand growth in and price increase, depletion resources and supply monopolize, climate change is forcing the restructuring of energy and other industrial and transport area, seeking for alternative energy sources (AES). The main direction of this operation - a wider use of renewable energy. The most prominent feature of this policy reflection can be considered in 2009, the European Parliament and of the Council formulated the objective - the famous "20, 20, 20" formula, which means that by 2020, the EU commits to a $20 \%$ increase in energy efficiency, $20 \%$ reduction in carbon dioxide emissions and consumption none less than $20 \%$ of energy from renewable energy sources (Lukoševičius Kalpokas, 2010; Directive..., 2009).

One of these AES policys range is biogas production and use. For biogas production are used easily degradable organic material (biomass) and waste (manure, food and beverage industries). Processing agricultural, municipal and other organic waste, avoids additional waste disposal costs during transportation or accumulating in landfills. Furthermore, considered, that the biogas production process does not affect the atmosphere of carbon dioxide increase, therefore not surprising that biogas production is becoming increasingly important both in Europe and in Lithuania, and its production potential is very high (Čiutelytė 2013, Perspectives of..., 2012).

More attractive and more applicable to the production of biogas is plants biomass growing. These herbaceous plants like reed canary grass, tall fescue, orchard grass, yellow sweet clover, perennial lupine, or non-traditional agricultural crops like giant miscanthus, cup plant, Virginia mallow, wormwood, Jerusalem artichoke has a huge energy potential and high biomass yield (Navickas et al., 2006; Butkutė et al., 2013; Kryževičienė et al., 2005; Tilvikienė et al., 2012; Sakalauskas, 2014; Sendžikienè et al., 2012). Moreover, such plants growing in the uncultivated land bring a double benefit - farmers receive payments for the non-use of land for food and feed uses and income for the grown biomass, processing it for energy purposes (Liubarskis, Navickas, 2007). Biogas production from biomass is a closed nutrient and carbon cycle, from raw material production to the substrate use as a fertilizer. The most of carbon, nitrogen, phosphorus and potassium remain in the substrate, whereby fertilized fields fully improve the soil. The substrate can replace chemical fertilizers, which production uses a lot of fossil fuels and energy (Seadi et al., 2008). Moreover, there is the possibility of energy crop cultivation in a free, unused, abandoned or anthropogenic pollution in the affected lands, which are currently not lacking (Tripathi et al., 2016).

Copyright (C) 2017 The Authors. Published by Aleksandras Stulginskis University. This is an open-access article distributed under the terms of the Creative Commons Attribution License (CC-BY 4.0), which permits unrestricted use, distribution, and reproduction in any medium, provided the original author and source are credited. 
The direct measurements data show that both the soil and groundwater usually exceed the limit contamination levels of oil hydrocarbons (Januseviciute et al. 2015). Self-purification is very limited, slow, some of the cases are not possible, and without purposeful human intervention xenobiotic compounds in the environment is not decontaminated effectively (Kalėdienè, 2009). Traditional soil treatment methods require a lot of resources: large labour resources, energy and time. Thus effective environmental remediation technology is economically attractive (Rubežius, Venslauskas, 2015). One of these new, low-cost technologies are phyto-cleaning technology, which adapt the unique abilities of plants to absorb contaminants, promoting their degradation or transformation which are used for final soil clean-up (Rubežius, Venslauskas, 2015). Previously performed studies show that properly selected perennial grasses can be grown in low or medium anthropogenic contamination damaged soils. Therefore arise the possibility of applying phytoremediations methods to biomass engineering, simply can create close raw extraction for energy purposes and low or medium anthropogenic affected areas restoration system.

The aim is to investigate the oil products contaminated soil remediation with plants and their biomass conversion to biogas, on purpose to create a closed cleaning and plant biomass utilization system. This study is closely related to previously conducted authors researches (Rubežius et al., 2016), which was to evaluate the herbaceous plants abilities of cleaning soil contaminated by oil hydrocarbons.

\section{RESEARCH METHODS AND CONDITIONS}

\section{The selection of plants}

Plants were selected according to soil structure and soil type, $\mathrm{pH}$, moisture content, the contamination source (chemical composition), the ability to assimilate pollutants. These plants are low-maintenance and low-demanding for special growing conditions. Choice of 3 different herbal plant species: E-1 - poaceae plant family; E-2 - amaranthus plant family; E-3 - poaceae plant family.

E-1 - A perennial herb, forage, is very fertile, resistant to drought and frost, 0.6-1.5 m tall, poaceae family plant. The root system is very strong, and therefore forms a very hard turf. The plant is a little demanding on soil, fertilizer and herbicide use, resistant to leaf fungal diseases. This plant is used for biogas, second-generation bio-ethanol production and direct burn (Vilkonis, 2008; Jakiene et al., 2013).

E-2 - adventitious, annual herbaceous, decorative, edible, 0.20-1.20 m tall, amaranthus family plant. It is grown as field crops, farms and cities. Grows well in poorer soil, well withstand drought and heat, almost not attack by pests. It has high heavy metals and petroleum hydrocarbons assimilative properties. From this plant can be produced high quality silage (Vilkonis, 2008; Jakiene et al. 2013).

E-3 - perennial grasses, decorative, poaceae family plant. Grows between 0.5 and $1.5 \mathrm{~m}$ in height, while the roots penetrate to a depth of 3 meters. In Lithuania this plant is rare. For eligibility for poor soil and climatic conditions, rapid growth and low demand for plant-care products are considered to be good candidates for biofuel and bio-ethanol production (Vilkonis, 2008, Lithuanian Energy Institute, 2011).

\section{Biomass preparation}

Selected plants were grown on the plot, which is the Kaunas region municipality, Raudondvaris town, Didvyriu street. Lithuanian Geological Survey the study results showed that the test object as a primer and ground water is contaminated with petroleum products. Concentration of oil products exceeded the established allowed limit values (200 $\mathrm{mg} / \mathrm{kg}$ ) in soil and the pre-set maximum concentration of oil products, with this value exceeded 72.6 times. Also it was found that the soil pollution exceeds the limits of multicyclic aromatic hydrocarbons (chrysene, benzo (b) fluoranthene, benzo (a) pyrene) (Grota, 2010).

Depending on the extent of pollution and geological and hydrological characteristics in the test area, there were distinguished four plots, $1 \mathrm{~m}^{2}$ for each selected plant species. The rest of the territory remained as a control. The soil is cultivated by hand: loosen to a depth of $20-25 \mathrm{~cm}$, by removing bulky waste (bricks, stones and etc.). Later the soil was homogenized. According to the recommendations of an effective agriculture technologies in line of the scientific research results and theoretical microorganisms nutrients needed, to ensure effective oil hydrocarbons conversion, every area fertilized with mineral NPK (16:16:16) fertilizers (300 kg/ha, $48 \mathrm{~kg} / \mathrm{ha}$ ). Research plots re-fertilized after 38 days.

After 84 (E-1) and 134 (E-2, E-3) days exposure test plants biomass was chopped to 3-6 mm size particles and ensile in 2 liter jars for at least 60 days. It is necessary to mention that the second half of summer (in 2015) was special in many districts of Lithuania was announced drought. According to the meteorological stations and agrometeorology data, it has been very dry in southern Lithuania and in the central regions of the country. It was found that the temperature of August in many districts was from $2.9^{\circ} \mathrm{C}$ to $3.8^{\circ} \mathrm{C}$ higher than the standard rate of climate (SRC), and in a larger part of the country, during the month, rain fell only 2-16 mm (3-20\% SRC) (www.meteo.lt). The selected plants are resistant to drought, but the high temperatures and lack of rainfall had apparently clear impact on plant growth and development. Because of these factors the dry part of plants investigated was of groups E-3 and E-2. Plant group E-1 biomass was taken a month earlier (07.24.2015) therefore the greater effects of drought were avoided and green plant biomass was measured.

\section{Methodology of anaerobic digestion}

Experiments were conducted on laboratory scale vertical type anaerobic digester (Fig.1) with three replications. Laboratory digester consists of a $20 \mathrm{~L}$ stainless steel vessel with active volume of $19 \mathrm{~L}$. Substrate is mixed by stirrer driven by electric gear. The intensity of mixing is in $30 \mathrm{~s}$ periods with $10 \mathrm{~min}$ pause. The temperature in the digester is 
automatically controlled. Data of temperature and $\mathrm{pH}$ of substrate, biogas yield and composition are recorded by programmable logic controller and stored in the computer database. Produced biogas is collecting at the top of digester and goes through the volumetric drum type biogas flowmeter to gasholder. The collected biogas is analysed by Awite AwiFlex analyser. The methane and carbon dioxide concentrations were measured. During the experiments the $39{ }^{\circ} \mathrm{C} \pm$ $0.5^{\circ} \mathrm{C}$ incubation temperature was used. Biomass is added through the tube on the top of digester and digested substrate drains to the digested substrate vessel. Iinoculum was taken from piggery farm biogas plant with addition of grass silage. After acclimation period (6 months) the experiments were started.

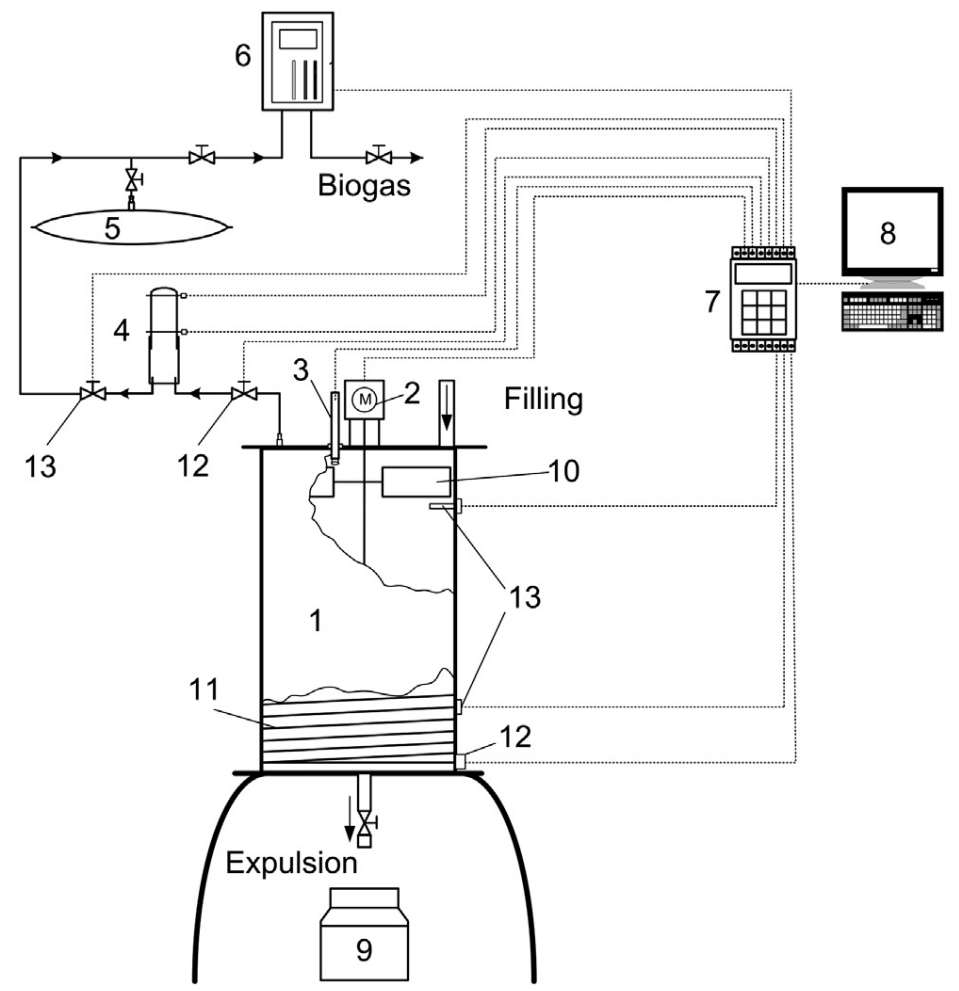

Figure 1. Laboratory anaerobic digester: 1 - digester, 2 - gear of mixer, 3 - pH electrode, 4 - biogas flowmeter, 5 - gasholder, 6 biogas analyzer, 7 - programmable logic controller, 8 - computer, 9 - digested substrate vessel, 10 - mixer, 11 - heater, 12 - relay of heating system, 13 - temperature sensors.

In this study, biogas was obtained from $123.94 \mathrm{~g}$ of silage of E-1 plants, $119.72 \mathrm{~g}$ of silos of E-2 plants and $100 \mathrm{~g}$ of E-3 plants silos. The latter in the laboratory reactors were maintained until the biological degradation of the full organic material. The sample size is selected based on the amount of dry organic matter (DOM).

Biogas yield, biogas volumetric yield and other paremeters were calculated according earlier described methodology (Vitkus, 2008; Venslauskas, 2009; Navickas, Venslauskas, 2008; Navickas et al., 2003).

\section{Plant chemical analysis results}

Studies on the chemical composition of plants were performed at the Agrochemical Research Laboratory of the Lithuanian Center for Agrarian and Forest Sciences. The methods used for the research are presented in Table 1.

Table 1. Plant chemical analysis results

\begin{tabular}{|l|l|}
\hline Researches parameter & The methods (mark) \\
\hline Dry matter \% & LST EN 12880:2002 \\
\hline In dry matter: & \\
\hline Organic material \% & LST EN 15 169:2001 \\
\hline Total nitrogen $(\mathrm{N}) \%$ & LST EN 13342:2002 \\
\hline Total phosphorus (P) $\%$ & LST EN 13650:2006, LST EN ISO 6878:2004 \\
\hline Total potassium (K) \% & LST EN 13650:2006, ISO 9964-3:1993 \\
\hline Organic carbon (C) $\%$ & ISO 10694-1995 (dry combustion) \\
\hline
\end{tabular}

\section{RESULTS AND DISCUSSION}

\section{Biogas yield results}

Biogas yield research of the selected plant biomass were started from plants chemical analysis, which revealed the dry matter (DM), dry organic matter (DOM), NPK and organic carbon. Plant chemical analysis results are presented in Table 2. 
Table 2. Results of plants chemical analysis

\begin{tabular}{|l|c|c|c|}
\hline Parameter & Sample code and results of the study & E-2 \\
\hline & E-1 & E-2 & 52.11 \\
\hline Dry matter \% & 15.56 & 53.74 & \\
\hline In dry matter: & & & 91.36 \\
\hline Organic material \% & 85.09 & 85.57 & 2.27 \\
\hline Total nitrogen (N) \% $\%$ & 3.45 & 2.76 & 0.30 \\
\hline Total phosphorus (P) & 0.58 & 0.51 & 2.40 \\
\hline Total potassium (K) \% & 4.2 & 4.40 & 34.9 \\
\hline Organic carbon (C) \% & 44.6 & 31.7 & \\
\hline
\end{tabular}

E-1 poaceae family plants; E-2 amaranthus family plants; E-3 poaceae family plants

In comparison of the biogas yield from selected plants biomass was observed, that the maximum biogas yield of selected plants DOM, received from anaerobic processing of the E-3 plants biomass, the lowest - E-1 plants biomass (Fig. 2).

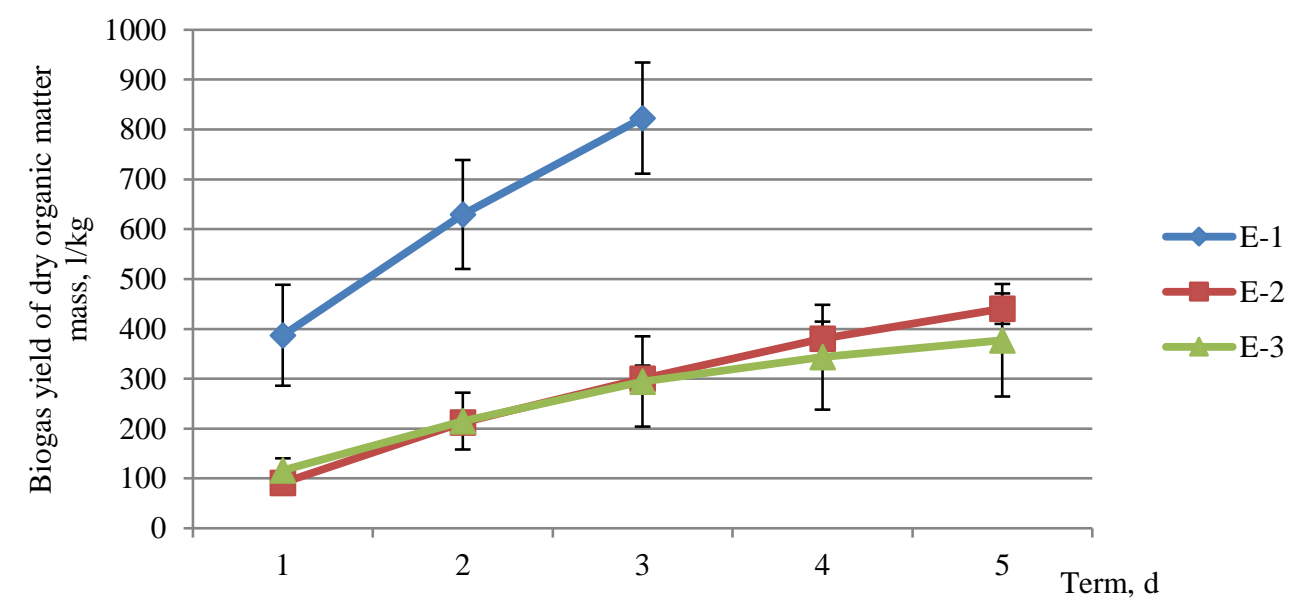

Figure 2. Biogas yield averages of single loads of dry organic matter mass. E-1 poaceae family plants; E-2 amaranthus family plants; E-3 poaceae family plants.

Also in 2 figure can observe that the fastest biological degradation of organic matter by anaerobic manner, took place E-1 processing plant biomass - an average of 2 days less than the processing of other plant biomass.

\section{Biomass energy conversion efficiency results}

Table 3 represent biomass energy conversion efficiency results. From this tabale we can see, that the best biomass energy conversion performance indicators identify to produce biogas from E-1 plant biomass, the worst - of the E-3.

Table 3. Biomass energy conversion efficiency results

\begin{tabular}{|l|l|l|l|l|l|l|l|l|l|}
\hline $\begin{array}{l}\text { Plant } \\
\text { code }\end{array}$ & $\begin{array}{c}\text { Biomass retention } \\
\text { term, d }\end{array}$ & $B_{D M}, 1 / \mathrm{kg}$ & $\begin{array}{c}B_{D O M}, \\
1 / \mathrm{kg}\end{array}$ & $B_{M}, 1 / \mathrm{kg}$ & $\begin{array}{c}C_{4}, \\
\%\end{array}$ & $\begin{array}{c}e_{b}, \\
\mathrm{MJ} / \mathrm{l}\end{array}$ & $\begin{array}{c}e_{M}, \\
\mathrm{MJ} / \mathrm{kg}\end{array}$ & $\begin{array}{c}e_{D M}, \\
\mathrm{MJ} / \mathrm{kg}\end{array}$ & $\begin{array}{c}e_{D O M}, \\
\mathrm{MJ} / \mathrm{kg}\end{array}$ \\
\hline $\mathrm{E}-3$ & 5 & 363.65 & 377.22 & 173.87 & 53.1 & 0.0187 & 3.25 & 6.80 & 7.05 \\
\hline $\mathrm{E}-2$ & 5 & 372.71 & 440.62 & 200.30 & 53.5 & 0.0189 & 3.79 & 7.04 & 8.33 \\
\hline $\mathrm{E}-1$ & 3 & 635.76 & 822.92 & 98.93 & 58.8 & 0.0208 & 2.06 & 13.22 & 17.12 \\
\hline
\end{tabular}

E-1 poaceae family plants; E-2 amaranthus family plants; E-3 poaceae family plants

\section{DISCUSSION OF TEST RESULTS}

Previously authors carried out soil research in a selected area before and after plant cultivation. Rezults proved to, that select plants can be used in oil-polluted soil treatment at 223 to $594 \mathrm{mg} / \mathrm{kg}$ of petroleum hydrocarbon concentrations in soil. It emerged that, using E-2, E-1, E-3 plants, soil pollution with oil products respectively decreased by $3.2 ; 2.2$ and 1.6 times. In all test cases, oil content in soil was below or slightly above the threshold value of total oil amount of the products, which is $200 \mathrm{mg} / \mathrm{kg}$. In such pollution, it is enough only one phytocleaning period in order to reduce pollution below the limit. At these levels endurance limit of the plants (plants death limit) was not reached, visual petroleum hydrocarbon toxicity effects were not observed. The concentration of multicyclic aromatic hydrocarbons (chrysene, benzo (b) fluoranthene, benzo (a) pyrene) in the soil after the selected plant growth exposure was not determined. However, it is assumed that the process of phytoremediation had positive degradation affect of these organic pollutants in soils.

The evaluation of the biogas yield and energy conversion efficiency rezults, ascertained, that the best results were achieved by processing E-1 plant biomass, the worst the E-3. It should also be noted, that the E-1 kept less than 2 days neither other plants biomass and that the E- 1 case used of at least a singles charges $(100 \mathrm{~g})$. Therefore, asessed the abovementioned rates, we can assume, that the selected plants most profitable to produce gas from the E-1 biomass. 
Assessment of all the biogas yield and energy conversion efficiency of the investigation, we can do conclude, that all choose plants basically suitable for the production of biogas, because biogas energy value is directly related to the concentration of methane, whose a minimum value necessary for gas combustion devices is 50-55\%. Exceeded minimum concentration of methane, biogas as a valuable fuel (Liubarskis, Navickas, 2007). Furthermore, a comparison biogas yield rezults with biogas yield from the other raw materials, which is used for production of biogas, the biogas yield from the selected plants is equivalent to and in some cases exceeds the biogas yield from such materials as: milk processing waste, meat industrines waste, vegetable waste, corn silage, which is considered as productively raw materials for the production of biogas (Budrys, 2006; Liubarskis, Navickas, 2007).

Recycled substrate studies have not been performed, but it is considered, that the elemental substrate composition has a little different from the elemental composition of raw materials. Of course, to determine NPK levels unmatched by mineral NPK fertilizer, but similar or better rezults as mineral fertilization, can achieve to enlarge recycled substrate fertilisation rate (Kadžiulienè et al. 2015; Barbosa et al. 2014). The Kadžiulienè et al. researchers presented data shows, that biogas production process recycled substrate fertilized herbage yield is higher fertilisation to $360 \mathrm{~kg} / \mathrm{ha}$ nor fertilising them with mineral fertilizers same rate $(360 \mathrm{~kg} / \mathrm{ha})$. Increasing biogas recycled substrate rate up to $450 \mathrm{~kg} / \mathrm{ha}$ is obtained an even better result (Kadžiulienè et al., 2015). Such organic fertilizer replacement provides additional benefits by: reducing the energy consumption of fertilizer production and transportation, environmental pollution illocal minerals, improves soil characteristics. In addition, the bioreactor recycled biomass activated soil microorganisms and enzyme activity (which is especially important during phytoremediation), is homogeneous and evenly spread on the fields (this is very important on purpose balanced fertilization). It can be composted or use concentrated fertilizer production (Sendžikienė et al. 2012; Liubarskis, Navickas, 2007).

\section{CONCLUSIONS}

1. Using E-2, E-1, E-3 plants the soil pollution with oil products can be reduced from 1.6 to 3.2 times. Proven, that in all tests cases the soil volume of oil products was lower or slightly higher than the threshold value of the overall petroleum products, which is $200 \mathrm{mg} / \mathrm{kg}$.

2. Assessed iogas yield and energy conversion efficiency rate, we found, that all of the selected plants biomass is suitable raw material for the production of biogas. Selected plant energy potential is from 377.22 to 822.92 liters / $\mathrm{kg}$ of DOM biogas with energy value, respectively, from 7.05 to $17.12 \mathrm{MJ} / \mathrm{kg}$ of DOM.

3. Assessed all mentioned aspects, can be said that the sued a scientific hypothesis is completely confirmed - selected crops reduce soil pollution with oil products, the processing of the biomass in the bioreactor, get good biogas yield and the energy conversion efficiency results, and theoretically proved that the processed substrate is not fair fertilizer than mineral fertilizers.

\section{REFERENCES}

1. Barbosa P. B. D., Nabel M., Jablonowski D. N. 2014. Biogas-digestate as nutrient source for biomass production of Sida hermaphrodita, Zea mays L. and Medicago sativa L. Energy Procedia, Vol. 59, pp. $120-126$. https://doi.org/10.1016/i.egypro.2014.10.357

2. Budrys, R. 2006. Management of sewage sludge and biodegradable waste. The 9th Lithuanian Young Scientists' Conference "Science - The Future of Lithuania", material of the reports, 30 d. March 2006 y. Vilnius, pp. 30-39 [In Lithuanian].

3. Butkutė B. N., Lemežienė N., Kanapeckas J., Navickas K., Dabkevičius Z., Venslauskas K. 2014. Cocksfoot, tall fescue and reed canary grass: Dry matter yield, chemical composition and biomass convertibility to methane. Biomass and Bioenergy, Vol. 66, pp. 1-11. https://doi.org/10.1016/j.biombioe.2014.03.014

4. Čiutelytė R. 2013. Biogas yield and quality improvement and purification with natural minerals. Aleksandras Stulginskis Universitety. Akademija: 101 p. [In Lithuanian].

5. Directive 2009/28/EC of the European Parliament and of the Council of 23 April 2009 on the promotion of the use of energy from renewable sources and amending and subsequently repealing Directives 2001/77/EC and 2003/30/EC. Available at: http://eurlex.europa.eu/legal-content/LT/TXT/?uri=celex:32009L0028 (Accessed on 16/11/2017)

6. Grota. 2010. Impact assessment of contaminated sites. Impact assessment of contaminated sites. Potential pollution object No. 10450 (petroleum base, Kaunas district, Raudondvaris, Didvyrių St.) results of detailed ecogeological research. Grota company and Lithuanian Geological Survey: 34 p. [In Lithuanian].

7. Jakienè E., Liakas V., Klimas E., Bačkaitis J. 2013. Technologies for growing energy crops and woody plants. Instructional book. Academy: ASU Publishing Center, 199 p. [In Lithuanian].

8. Kadžiulienė Ž., Karčiauskienė D., Bakšienė E., Tilvikienė V. 2015. Biomass of agricultural crops for biogas. Materials of the conference "Biogas: Environmental, Technological, Economical Aspects", Vilnius, pp. 17. [In Lithuanian].

9. Kaledienè L. 2009. Microbiological studies of soil bioremediation. An overview of the scientific work submitted for the habilitation procedure. Vilnius University.Vilnius, 42 p. [In Lithuanian].

10. Kryževičienė A., Navickas K, Župerka V. 2005. Use of perennial grasses for biogas production. X LUA Scientific Works, No. 69 (22), 8 p. [In Lithuanian].

11. Kulikauskas T. 2008. Study of the energy efficiency of biogas production from plant biomass. Master final thesis. Lithuanian University of Agriculture. Academy, 54 p. [In Lithuanian]. 
12. LHMT. 2015a. Lithuanian Hydrometeorological Service under the Ministry of Environment. Dandruff is detected. 2015.07. Available at: http://old.meteo.lt/naujiena.php?id=679 (Accessed on 08/09/2015) [In Lithuanian].

13. LHMT. 2015b. Lithuanian Hydrometeorological Service under the Ministry of Environment. 2015 y. August m. overview. 2015.08. Available at: http://www.meteo.lt/lt/menesio-apzvalgos/2015-rugpjutis (Accessed on 08/09/2015) [In Lithuanian].

14. Lithuanian Energy Institute. 2011. Sustainable Energy. Kaunas: 36 p. [In Lithuanian].

15. Liubarskis V., Navickas K. 2007. Biogas - opportunities and perspectives: study. Raudondvaris: 49 p. [In Lithuanian].

16. Lukoševičius V., Kalpokas V. 2010. Ten years program for the development of the use of renewable resources in the district heating $\begin{array}{llllllll}\text { sector. Thermal technology. } & \text { Nr. } & 5 & \text { (Nr. } & 42), & \text { P. } & 8-9 . & \text { Available at: }\end{array}$ http://www.lsta.lt/files/Leidiniai/SILUMINE_TECHNIKA/Silumine\%20technika\%20(42).pdf (Accessed on 09/12/2015) [In Lithuanian].

17. Navickas K., Župerka V., Janušauskas R. 2003. Use of perennial grasses for the production of biogas. Works of the LUA Institute and LUA. No. 35 (4), pp. 109-116. [In Lithuanian].

18. Perspectives for Biogas in Europe. 2012. Oxford Institute for Energy Studies, 54 p.

19. Navickas K., Župerka V., Venslauskas K., Kryževičienė A. 2006. Energy consumption for biomass production and preparation for biogas production. Works of the LUA Institute and LUA, No. 38 (3), pp. 51-58. [In Lithuanian].

20. Navickas K., Venslauskas K. 2008. Bioenergy theoretical foundations. Methodological advice for laboratory works and exercises. Akademija: 31 p. [In Lithuanian].

21. Rubežius M., Venslauskas K. 2015. Overview of contaminated soil phytoremediation methods. Agroengineering and Energetics, No. 20, pp. 62-68. [In Lithuanian].

22. Rubežius M., Venslauskas K., Kidikas Ž. 2016. Herbaceous energy crops for cleaning of soils contaminated by petroleum hydrocarbons. Agricultural Engineering, Vol. 48, pp. 1-7.

23. Seadi T., Rutz D., Prassl H., Kottner M., Finsterwalder T., Volk S., Janssen R. 2008. Biogas handbook. Esbjerk: 126 p.

24. Sendžikienè E., Kalenska S., Makarevičienė V. 2012. Biogas - alternative fuel for transport. Aleksandras Stulginskis University. Kaunas: 48 p. [In Lithuanian].

25. Tilvikienė V., Venslauskas K., Navickas K., Župerka V., Dabkevičius Z., Kadžiulienė Ž. 2012. The biomass and biogas productivity of perennial grasses. Žemdirbystè=Agriculture. Vol. 99, No. 1, pp. 17-22.

26. Tripathi V., Edrisi S.A., Abhilash P.C. 2016. Towards the coupling of phytoremediation with bioenergy production. Renewable and Sustainable Energy Reviews, Vol. 57, pp. 1386-1389. https://doi.org/10.1016/j.rser.2015.12.116

27. Venslauskas K. 2009. Reduction of environmental polution by utilisation of agricultural organic wastes to biogas. Doctoral dissertation manuscript. Lithuanian University of Agriculture. Akademija, 94 p. [In Lithuanian].

28. Vilkonis K. K.. 2008. Lithuanian green dress. Kaunas: Lutute, 408 p. [In Lithuanian].

29. Vitkus V. 2008. Investigation of the energy consumption of biogas production from sludge. Master final thesis. Lithuanian University of Agriculture. Akademija, 60 p. [In Lithuanian]. 